\title{
English Education and Large Classes: Unpacking the Challenges and Coping Strategies
}

\author{
Dian Erlina \\ Universitas Islam Negeri Raden Fatah Palembang, Palembang, Indonesia \\ Lenny Marzulina \\ Universitas Islam Negeri Raden Fatah, Palembang, Indonesia \\ Kasinyo Harto \\ Universitas Islam Negeri Raden Fatah, Palembang, Indonesia \\ Muhammad Holandyah \\ Universitas Islam Negeri Raden Fatah Palembang, Palembang, Indonesia \\ Bunga Ayu Wulandari \\ Universitas Jambi, Jambi, Indonesia \\ Muhammad Fauzan \\ Universitas Jambi, Jambi, Indonesia \\ Fridiyanto Fridiyanto \\ UIN Sulthan Thaha Saifuddin Jambi, Indonesia \\ Amirul Mukminin \\ Universitas Jambi, Jambi, Indonesia
}

\begin{abstract}
The purposes of our study were to explore the perceptions of English teachers' on the challenges and the strategies in teaching large classes. Our participants were English teachers. We investigated the case in two large classes through a qualitative case study. We employed observations and interviews to collect the data. To analyze the qualitative data from observations and interviews, the thematic analysis was used. We analyzed the data first by putting all the data into computer files and the filed folders after transcribing the raw data into texts. Then, we began making codes for all of data and themes that are related to our research questions. The last, we presented the table of themes and codes into the findings and results. Based on the data analysis, we found seven important challenges encountered by our participants in teaching large classes including poor class conditions, difficulties or problems in controlling/monitoring the discipline of their students, the equality of attention to students, difficulties or problems in evaluating their students, ineffectiveness or uselessness of learning processes, deficient interest in learning English, the dominant use of local languages. In terms of strategies, we found six important strategies employed by our participants in dealing with the challenges including punishment, variety of games, quiz, pair work or group work, supporting media, and speaking test. In conclusion, our participants faced teaching challenges while they also found some approaches or methods to deal with the problems.
\end{abstract}

Index Terms - challenges, perception, teaching large classes

\section{INTRODUCTION}

Language is very important as a communication tool for every individual in his or her daily life. In the words of Finch (2003), for certain individuals or groups in delivering their thoughts in various activities, language is a system of communication. Additionally, language is used for having a communication with other people and it makes it easier for them to interact with each other (Marzulina, 2018). For example, English is as one of the international languages that are used by many people. Abrar et al. (2018) argue that it is extensively recognized that English is an international language as it has been generally spoken among foreign language speakers. Additionally, Herlina and Holandyah (2016) state that people from diverse nations communicate with each other by using English as their international language. Considering that English is very widespread, henceforth, it has an exceptional place in educational settings in numerous nations, including Indonesia. In Indonesia, schools are required their students to learn English from elementary to high school which finally may facilitate students to interact easily with other people from different nations (Hamra and 
Syatriana, 2010) while Abrar and Mukminin (2016) also argue that English has an important position in Indonesian educational system in which it is one of the compulsory subjects that must be learnt by the students from senior high schools to a university level (2016 as cited in Marzulina, 2018). Furthermore, the 2003 Law on the Indonesian educational system places English as the first foreign language among other foreign languages such as German, Arabic, or Japanese (Abrar et al., 2018). Accordingly, in respect of the worldwide competitiveness, communication, relations, and information and of the dominant use of English all over the world, a number of innovative agendas engaging students have been presented by educational stakeholders around the world which may embrace a more promise of accomplishment for students' cognitive, linguistic, and academic achievement (Mukminin et al., 2019).

As the schools are mandatory to provide students with English subject, the role of the teacher in the English classes is very significant to ensure teaching and learning processes run well. Day and Sammons (2014) argue that a teacher is a person who has the key to help students have success in learning such as science, language, or others is a teacher while Habibi et al. (2018) argue that classroom management is particularly important in teaching English as a foreign language because it is one of the influential factors in students' success in learning English. Furthermore, Brown (2001) state that classroom management is related to the techniques that every teacher has to keep the students controlled, orderly, attentive and industrious for the duration of a class, as a consequence teachers must have knowledge of classroom management. He also adds that it also includes maintaining classroom discipline such as addressing misbehavior and giving rewards and punishment. Classroom management could be defined as a collection of techniques and skills allowing every teacher to manage students effectively so as to generate an encouraging learning setting for all students. Thus, teachers have to know about classroom management properly, since it influences the teachers to build and maintain workable system in the classroom.

Classroom management mastery in teaching and learning process is influenced by the class size. Wilson (2002) defines that class size refers to the number of students in a given classroom whether it is small or large. Additionally, class size will influence the activities in teaching and learning process. Brown (2009) states that class size will affect teaching and learning activities, such as on classroom management and assessment. Wilson (2006) also adds that different type of class sizes will also have different impacts on teaching. He states that all students who are in a small class will understand the material easily because the teachers can transfer their knowledge to the students one by one. On the other hand, teachers will face many challenges in teaching large class such as classroom management, student control and marking, planning and assessment. In short, the number of students in small and large classes can challenge the teachers in their classroom management and assessment. Based on explanations above, it can be concluded that large class is considered as one of the biggest challenges faced by teacher in the classroom.

Nowadays, large classes become a universal phenomenon. Brown (2001) affirms that the appropriate language classes should have twelve students. It means that a class which consists of more than twelve students is considered as a large class. Haddad (2015) adds that the number of more than 25 students taught by one teacher is considered large class. Based on definitions above, it can be concluded that large class is the class situation where the number of students are more than twenty five students per one teacher. Many teachers assumed that large classes bring many difficulties in teaching and learning process. Hayes (1997) states that the challenges encountered by teachers in teaching large classes are divided into five parts: (1) discomfort, (2) control, (3) individual attention, (4) evaluation and (5) learning effectiveness. Brown (2001) also adds there are four challenges that commonly present in teaching large classes: (1) students' proficiency and ability, (2) teachers' and students' attention, (3) students' opportunities, and (4) teachers' feedback. In short, large classes are the major problem in some schools faced by the teachers in teaching and learning process. The purposes of our study were to explore the perceptions of English teachers' on the challenges and the strategies in teaching large classes with the research problems: (1) What are the English teachers' perceptions on the challenges in teaching large classes at a private school? (2) How do the teachers of English at a private school cope with the challenges of large classes?

\section{LITERATURE REVIEW}

Teacher encounters many challenges in teaching and learning process. Younghusband (2005) states that there are several problems perceived by the teachers such as: (1) teachers are burdened with big responsibility in maintaining the classroom; (2) teaching difficulty related to class size; (3) students are misbehaved in the classroom; (4) inadequate supervision tools, teaching resources and professional training; (5) no specific skill is being taught; and (6) lack of time and evaluation in teaching and learning. Pickering (2008) supports that some challenges encountered by the teachers in the classroom are divided into three: (1) teachers have no additional time and resources in teaching; (2) teachers are unable to control the students in large classes; (3) the disruptive students are united in making some noise. Accordingly, those challenges will encounter the teachers with the result that teaching and learning process will not be effective.

Large classes are the part of class size which becomes a universal phenomenon nowadays. Rohin (2013) defines that large class refers to the number of students who are too many to learn in a given classroom. The problem of large classes have been also studied by Hayes (1997), Coleman (1989) and Ur (1996), they said that a large class is one where the students are more than the teacher wishes to manage and where pedagogical resources are inadequate in relation to the number of students. This view is also supported by Todd (2006) who adds that the teachers' judgments of the total number of the students in a classroom will mark the definition of large classes. Though large classes do not have the 
exact size, some experts claim that it is measured by the number of students per teacher. Brown (2001) affirms that the appropriate language classes should have twelve students. It means that a class which consists of more than twelve students is considered as a large class. Haris and Plank (2000) claim that a small class size is described as a class with roughly 15 students, while a large class size is described as a classroom with around 24 or even more students. Haddad (2015) defines that the number of more than 25 students taught by one teacher is considered as a large class. It can be said that a large class is the class with the number of students that are more than 25 students that are taught by one teacher.

Large classes have created a number of challenges to the teachers. Hayes (1997) affirms that the challenges encountered by teachers in teaching large classes are divided into five parts: (1) discomfort, (2) control, (3) individual attention, (4) evaluation and (5) learning effectiveness. In supporting Hayes' statement, Brown (2001) adds that there are four challenges that commonly present in teaching large or big classrooms including proficiency and ability very are widely across students, individual attention is decreased, students' opportunities to speak are narrowed, and feedback from teacher on student's written work is partial. Rohin (2013) also supports that large classes create lack of communication, discipline, assessment, and individual attention. In addition, British Council's (2015) report indicates a set of challenges in teaching large English classes such as students' disciplines, students' motivations, students' attentions, and students' preparations. In short, those challenges will influence the quality of teaching and learning processes.

\section{Methodology}

\section{A. Research Design, Research Site, Sampling, and Participants}

We did our current study by using a qualitative case study as Mukminin et al. (2019) claim that it was an intensive and holistic description and analysis of "a bounded system" on matters such as a person, an institution, a program, etc. The most important motive of using a qualitative case study is that it is an appropriate method to search every day behavior of teachers and students in classroom and describe the phenomenon happening to the teachers during the teaching and learning process. Therefore, we investigated the English teacher's perception on the challenges in teaching large classes and the strategies of coping with the challenges. The participants were two teachers of English at a private school. These English teachers were representative participants that were considered by their role (as the resident teachers), perspective (those who approved the intervention), experienced level (as the senior residents), and diversity (gender, ethnicity, or other backgrounds).

\section{B. Data Collection and Analysis}

In this study, the data were collected from classroom observations and interviews. The first instrument we used in order to gain the data was classroom observation which is the process of gathering open-ended, firsthand information by observing people and places at a research site (Creswell, 2012). The type of observation in this study that we employed was a non-participant observation. Leavy and Biber (2011) state that a non-participant observation refers to the way of conducting observation without being participated in the activities that you are observing. In addition, this study was also completed by observation checklists in order to help us to focus on aspects we wanted to investigate in the classroom. The observation checklist was adapted from Hayes (1997). The checklist was in the form of table with the criteria adopted from Hayes (1997) and with yes or no scale by having extra column for the notes. Furthermore, the second instrument that we used in order to complete the data was interview. Creswell (2012) affirms that a qualitative interview occurs when researchers ask one or more participants general, open-ended questions and record their answers. The interviews were conducted by having semi-structure interviews with one-on-one interview type.

In order to analyze the qualitative data gained from the observation and interview, we used thematic analysis. First, we collected the detail data from observation (e.g., observation checklists and field notes) and interview (e.g., transcriptions). We put the data into computer files and filed folders after transcribing the raw data into texts. Then, we started coding all of data and gave some themes that are related to our research questions. The last, we presented the table of themes and codes into the findings and results.

\section{Establishment of Trustworthiness}

Trustworthiness was used for evaluating qualitative data analysis to make sure that the findings were accurate and credible. Creswell (2012) states that strategies such as member checking or triangulation can be used to maintain the quality of the qualitative findings. In our study, we used a methodological triangulation which was classroom observations and interview. If the data of classroom observation and interview agreed, the findings were judged to be accurate and credible.

\section{RESULTS}

The findings were divided into (1) the English teacher's perceptions on the challenges in teaching large classes (2) strategies of coping with the challenges in teaching large classes. 


\section{A. English Teacher's Perception on the Challenges in Teaching Large Classes}

We found that there were several challenges encountered by the teachers of English in teaching large classes including poor class conditions, difficulties or problems in controlling/monitoring the discipline of their students, the equality of attention to students, difficulties or problems in evaluating their students, ineffectiveness or uselessness of learning processes, deficient interest in learning English, the dominant use of local languages.

\section{Poor Class Conditions}

We found the first challenge encountered by the teachers of English in teaching large classes was poor class conditions caused by dirty and unorganized seating arrangements, and hot classroom conditions. The data gained from the interviews showed that two teachers of English felt uncomfortable in teaching large classes caused by dirty and unwell maintained classrooms. Teacher YS said,

"It also triggers discomfort in the class, especially when there is garbage inside. Therefore, before teaching, I always say "throw the garbage in the bin, please!... and trim the table first" to the all students."

The data from observations showed that the classroom conditions were dirty and not well maintained. The students kept their rubbishes inside their desks even under their chairs too. This condition created unpleasant smell coming from the rubbishes which influenced the teacher's comfort in teaching large classes. Meanwhile, the seating arrangement in every classroom was also not well-organized. It was because the school had small and limited room capacities so the students must be compacted in one room inevitably. As a matter of fact, the school also had lack of desks and chairs for the students because some of their desks and chairs were broken. They used desks which are made from wood while some chairs were plastic chairs. This challenged the teachers when they wanted to move around the classroom for monitoring their students and for conducting group meetings. Furthermore, another cause that made the teachers of English uncomfortable in teaching large classes was the hot condition. This hot condition was caused by lack of school facilities such as fan and also the fan system was not functioning properly.

\section{Difficulties or Problems in Controlling/Monitoring the Discipline of Their Students}

We found that the teachers of English encountered some challenges in controlling students' discipline when they taught large classes. They had a difficulty in controlling some students in large classes especially when they made loud noise. Teacher RU said,

"Actually, it is a burden for me as a teacher in teaching many students in one class. It is because the students like making loud noise, disobeying the teacher, behaving bad behavior even if I punish them, they still do it later."

Additionally, based on the observation, we found that students tended to make louder noise than their teacher; it made the teacher of English seemed to speak in inappropriate volumes when delivering the materials. Therefore, some students could not hear the explanations of teacher clearly especially if they sat in the back that was far from the teacher.

\section{The Equality of Attention to Students}

The data gained from interview also showed that the English teachers did not know all their students' names in the large classes. They also did not know the number of female and male students in their classes. This challenge affected the interaction between teacher and students in the classroom, because the teacher tended to interact with some wellknown and active students in the classroom. Teacher YS claimed,

"It is very difficult for me to interact with all students in large classes because I do not even know all the students' name so that I just could interact with some students who are well known and active in the classroom."

Similarly, from the observation data, we found that the English teachers always mentioned several names when they delivered the materials, especially the names of students who were well-known and active in the classroom.

\section{Difficulties or Problems in Evaluating Their Students}

Based on data gained from interview, it showed that the teachers of English encountered some challenges in assessing their students. Some students did not complete their assignments such as exercises and homework on time. Moreover, they usually did their assignments by cheating, so their scores were not based on their knowledge purely. Teacher YS claimed,

"If the assignments are given like a written task, the students usually do not complete their assignments on time then, they usually cheat so, their scores are not based on their knowledge purely."

The data from observation showed that the teachers of English usually gave some exercises to their students after delivering the material in order to check their understanding. Unfortunately, some students often answered the exercises by seeing their friends' answers. When the time was up, most of students often did not complete their exercises on time so that the teachers asked them to do it as their homework. They felt unable to check all of the students' assessments such as exercise and homework due to lack of time. Teacher YS said,

"It takes a long time to check all the students' assignments such as exercise and homework because there are a lot of student assignments from another class that I have not checked yet and also time has spent for explaining the material."

\section{Ineffectiveness or Uselessness of Learning Processes}


Teaching and learning processes in large classes were not effective enough. It would influence the students learning outcome, most of students tended to be passive and did not make progress in learning, Teacher YS reported,

"Certainly not effective, because too many students in one class can make me difficult in controlling the students especially misbehavior students. It is also difficult in managing the time when I teach in accordance with the syllabus, and my concentration is also disturbed by some challenges. Moreover, most of students in large classes tend to be passive and do not make any progress in learning."

The data from observation showed that teaching and learning processes in large classes were not effective enough. It was caused by some challenges appeared in teaching large classes that would affect the ineffectiveness of learning and teaching as learning objectives were not achieved in accordance with the syllabus.

\section{Deficient Interest in Learning English}

Our finding revealed that the students who were not interested in learning English in our study might be caused by the status of English as a foreign language in the country. Other consequence of this was that students became lazy to learn English and they did not pay attention when their teacher explained the materials. Teacher YS reported,

"Teaching English in large classes is not easy because English is a foreign language for the students. Therefore, they have less interest in learning English. And also, most of students do not know the vocabulary or meaning of words or sentences in English. They are also lazy to bring their English dictionary which means that they have less motivation in learning English too."

\section{The Dominant Use of Local Languages}

Our finding revealed that the large classes affected the students' preference to use their local languages. Teacher YS said,

"Since the students do not know the vocabulary or meaning of words or sentences in English, therefore, they often use Palembang language. In fact, the students have difficulty in delivering their ideas in English and they often make mistakes in pronouncing the words in English."

The data gained from observation revealed that most of students preferred to use their local languages during teaching and learning activities in the classroom. When the teacher asked to use English, they directly felt shy and afraid of making mistakes. Therefore, they just responded the teacher's questions by saying yes or no or even kept silent.

\section{B. English Teacher's Strategies in Coping with the Challenges in Teaching Large Classes}

There were some strategies commonly used by the teachers of English in coping with the challenges in teaching large classes including punishment, variety of games, quiz, pair work or group work, supporting media, and speaking test.

\section{Punishment}

We found the strategy for coping with the challenges of controlling students' discipline during teaching and learning processes in large classes. In this study, we found that teacher used punishment in order to maintain the students' discipline in the classroom. Teacher RU said,

"I usually say "silent, please!" with a louder voice, if they still make some noise, I will call their name and ask them to re-explain the material I had delivered before as the punishment."

The data from observation showed that when the students made a loud noise in the classroom, the teachers warned them to be silent. In addition, when the students misbehaved or even disturbed teaching and learning activities, the teachers gave them punishment such as asked them to re-explain the material in front of the other students and gave the students additional assignments to do outside the classroom.

\section{Using Variety of Games}

We found that the second strategy commonly used by the teacher of English in order to cope with the challenges in teaching large classes. This strategy was using variety of games in order to attract the students' interest and attention in learning English. Teacher YS stated,

"I cope with the challenges of large classes by using some strategies in teaching English such as using game."

In addition, there were three kinds of game that used by the English teacher in teaching large class. Teacher YS stated,

"The games I employed in the large classes were letter scramble, word categories and chalkboard acronym."

The data from observation revealed that in the game of letter scramble, teacher asked the students to take a set of words that they had recently studied and wrote a scrambled form of each on the board. Then, teacher let the students to unscramble the words on their paper.

\section{Using Quiz}

We found that teacher used a quiz as a strategy for coping with the challenges in teaching large classes. This strategy was very useful in checking the students' understanding related to the materials explained. The data from interview above were supported by the data from observation. It found that the use of a quiz in teaching large classes was a good way to get students' attention and check their understanding about what they had been studying before. Teacher of English used short quizzes after explaining the materials to the students. In this strategy, teacher asked some questions 
then had the students to answer her questions. If they answered those questions correctly, she would give additional score and appreciated them inside the classroom.

\section{Conducting Pair Work or Group Work}

The findings revealed that another strategy for coping with the challenges in teaching large classes was conducting pair work or group work. One of teachers of English conducted group work to provide interaction and cooperation among the students in the classroom. For example, Teacher YS claimed, "I cope with the challenges of large classes by using some strategies in teaching English such as using games, quiz, pair work or group work in large classes." In line with the data gained from interview above, the data from observation showed that during observations, one teacher conducted group work once. In this group work activity, the teacher divided the students into eight groups and each group consisted of five or six students. After that, the teacher explained the group work rules and also explained what they had to do. Then, the teacher gave the students time allocation of 30 minutes to discuss it together. During discussion, the teacher monitored the students' activity while interacted with them. If the time was up, the teacher asked representative student from each group to deliver his/her group ideas. In short, the use of pair work and group work as in large classes played an important part since they maximized students' participation and solidarity.

\section{Using Supporting Media}

We found that using supporting media was a strategy in coping with the challenges in teaching large classes. In this strategy, teachers of English used a projector display as a supporting media for delivering the material. They believed that it could make students more interested in learning English. Teacher YS stated,

"I cope with the challenges of large classes by using some strategies in teaching English such as using game, quiz, and pair work or group work in large classes supporting with media which can make the students interest, comfort in the class, pay attention to the teacher and instruction well, then interact with other students."

Additionally, during observations, we found that both of English teachers did not use any supporting media as they mentioned in the interview due to lack of supporting media. Therefore, it can be concluded that teachers suggested the others to use supporting media such as a projector display in order to make the students more interested in learning English especially in large classes.

\section{Using Speaking Test}

Based on the data gained from interview, we found that the last strategy used by the teacher of English in coping with the challenges in evaluating the students was using speaking test. The use of speaking test as an evaluation for the students could minimize cheating and also provide individual feedback at the same time. Teacher YS said,

"Because English is a skill, I automatically evaluate the students by using speaking skill. We can see clearly and easily whether the students have skill or not when they speak English. If the assignments are given like a written task, the students usually do not complete their assignments on time then, they usually cheat so, and their scores are not based on their knowledge purely."

\section{DISCUSSION}

There were several challenges encountered by the teachers of English in teaching large classes. One of the challenges was a poor class condition. The teachers felt uncomfortable in teaching large classes caused by a poor class condition which was dirty and not organized with a good seat arrangement, and also hot condition. Firstly, some students usually stored their rubbishes inside their desks even under their chairs. Subsequently, unpleasant smell was coming during teaching and learning process. Therefore, it could make teachers feel discomfort and lose their concentration in teaching the lesson to the students. A classroom is needed to accommodate every student and teacher comfortably by cleaning and maintaining the classroom before starting teaching and learning activity. The other factor of discomfort was students' irregular seating. The result was in line with the findings of Hayes (1997) and Wang and Zang's (2011) studies that revealed that the students in large classes could not move easily and some students did not do the activities. Thus, a classroom is needed to be spacious enough and seats are needed to be arranged so that students could work each other and also could make them move around easily.

Furthermore, the other factor of discomfort was lacking and non-functioning of facilities provided by school in each large class. Every classroom needed adequacy of facility such as fan or air conditioner in order to comfort the teacher and students in the classroom during teaching and learning process. Unfortunately, this study found that each large class was facilitated only one fan by the school and it was not functioning properly. Due to small room and density of students in one class, it created feeling of hot and steamy atmosphere especially when the students studied at noon until afternoon so that teacher and students felt uncomfortable during the process of teaching and learning. This result was in line with Epri (2016) who found that the school site was experiencing shortages of facilities, that was why school had to provide additional facilities such as teaching and learning resources, classroom furniture, classroom space and teaching stuff. In short, the school needs to provide additional facilities especially fan or air conditioner in order to decrease heat condition in large classes.

In addition, we also found that the English teachers encountered some challenges in controlling their students during teaching in large classes. Some students usually made loud noise and misbehaved in the classroom. Although the 
teacher had tried to warn them to keep silent, his or her students stopped for a few minutes, but they made noises again. Once the students were doing so, they bothered other students. This result was in line with the studies of Lazear (2003), Rohin (2013), Plank and Candliffe (2011), British Council (2015), Sulistyowati (2012), Wang and Zang (2011) that claimed that it was difficult to keep good discipline going in a large class. Since there were many students in one class, too much noise could not be avoided. Hayes (1997) also argued that teachers felt unable to control large classes because too many students and they often made a loud noise.

Furthermore, the reason students in large classes often made a loud noise was that the teacher speak in inappropriate volume when delivering the material. Since the students could not hear the explanation clearly, they felt bored and misbehaved in the classroom especially if they were seated in back seat. This result was supported by Harmer (2010) and Zhang (2008) who claimed that making noise was a common problem in large classes which might come from students' tediousness as they were not able to comprehend the instructions of activities in the class and their teachers' voices were not louder enough. Ara and Hossain (2016) added that normally, students started making noises as they could not have their teachers' voices when they were sitting at back of the classroom and then they started talking, or even playing games among themselves with their smartphones. The factor that causes the teachers felt unable to control their students in large classes was because of narrow space. This result was in line with Hayes (1997) who stated that teachers felt that the physical restraints of a classroom with a number of tables and chairs often prohibited them from having interactive activities. Thus, the teachers had to consider which arrangement best enabled and allowed them to see and talk to the students, and also moved around easily to monitor their activities.

Subsequently, we also found several challenges faced by the English teachers in giving individual attention to their students. Hayes (1997), Brown (2001), Rohin (2013), British Council (2015), and Wang and Zang (2011) revealed that large classes made teachers in EFL class unable to pay individual attention to all learners since they did not even remember all the students' name. This result was in line with Epri's (2016) study that found that the teachers did not know all their students' names in their classes because the classes were too big and some students missed school often. Hayes (1997) added that calling students' name as one of the ways to control a class and it functions to establish good teacher-student relationships. Thus, using name is the initial step in showing students that teachers care about them as individuals. Furthermore, the English teachers also did not involve themselves in students' activity especially group work in the classroom. This result was supported by Epri (2016), Earthman (2002), and Hayes (1997) who reported that teachers in large size classrooms generally used the teacher centered teaching strategy. They stood in front, wrote, and explained things from the board. After that they put the students into groups, then gave worksheets to work while they spent much time on writing on the board. Therefore, most of students in large classes felt unnoticed by their teacher since they did not give individual attentions. Besides, the challenges that we had explained above, we also found some challenges encountered by the English teachers in evaluating their students during teaching and learning in large classes Teachers of English thought that it was difficult to do assessment in large classes. This result was supported by Rohin (2013), Epri (2016), Hadi and Arante (2015), and Hayes (1997) who claimed that assessment was difficult to do in large classes. It was caused by the amount of time spent on setting assessment tasks. On the other hand, most of students did not do or complete their assignments such as exercise and homework on time. In this case, they commonly answered the questions by cheating. This result was in line with Hayes (1997) who revealed that there was big possibility of students copying or cheating in large classes.

In addition, English teachers also had difficulties in assessing the large number of students and providing positive feedback within the limited time. This result was in line with Wang and Zang (2011), Hadi and Arante (2015), Ara and Hossain (2016), Epri (2016), Brown (2001) who believed that teaching English in large classes would be difficult for the English teachers to assess the whole students learning progress and when they wanted to measure students skills, they would spend too much time because assessing those skills requiring personal feedback. Based on explanations above, this was believed that teaching in large classes would not be effective since the teachers encountered some challenges in teaching and learning process. Additionally, teaching in large classes would not affect to students' achievement. This result was supported by Epri (2016), Hayes (1997), and Khan and Iqbal (2012) who argued that large classes did not affect learners' achievement than smaller classes. Thus, teachers had to think creatively about how to make learning in large classes effective and create positive learning environments. On the other hand, since the status of English was a foreign language in Indonesia education system, the students were not interested in learning English. They felt lazy and did not pay attention to the teacher's explanation in the classroom. This result was in line with Hadi and Arante (2015), Wang and Zang (2011), and Thaher (2005) who stated that EFL teachers who find students having lack of interest in learning English would lead them to be lazy to learn English. Other concern of this is that students might not pay attention to their teachers' explanations.

Another finding was found that the students in large classes often spoke their local language (Palembang language). It was caused by lack of vocabulary and practice English in the classroom. Therefore, when the teacher spoke English, they did not understand what the teacher talks about and they just answered teacher's questions by saying yes or no or even keep silent. This result was supported by Hadi and Arante (2015), Wang and Zang (2011) who found that a large class size influenced the students' preference to speak local language for practicing English. Finally, we also found that there were some strategies which teachers of English suggested to cope with the challenges in teaching large classes. The first strategy was giving a punishment to control disruptive students in the classroom. This result was supported by 
Ara and Hossain (2016), Sulistyowati (2012), and Trang (2015) who claimed that having a rule or punishment to monitor students' behaviors is vital in every classroom and for a large class, it is even more important. Furthermore, the use of games, quiz and pair work or group work in teaching large classes would be very useful in managing the classroom. This result was in line with Harmer (2007), UNESCO (2006), Trang (2015), Sulistyowati (2012), Hadi and Arante (2015) who claimed that using games or quiz and conducting pair work or group work were very effective strategies in managing a class with large number of students so that the teacher could make a good contact with every student and the students could receive individual attention from the teacher. Additionally, since the students in large classes had less interest in learning English, the use of supporting media would make them more interested in learning any subject especially English. This result was supported by Ara and Hossain (2016) and British Council (2015) who stated that in large classes, a teacher might be tired or unenthusiastic if his or her teaching way was unexciting. Therefore, using various teaching methods with supporting media would make the students more interested in learning English. In conclusion, since the students in large classes often did their assignments by cheating, the use of speaking test would help the teacher in minimizing cheating and also providing individual feedback. This result was in line with Ara and Hossain (2016) and UNESCO (2006) who revealed that speaking test involved giving students ample opportunities to practice English, minimize cheating activity and give feedback on the students' performance.

\section{CONCLUSIONS}

Teaching English as a foreign language is not easy for a country like Indonesian having many local languages and large classes. The findings of our study revealed that several imperative challenges in teaching English in large classes such as poor class conditions, difficulties or problems in controlling/monitoring the discipline of their students, the equality of attention to students, difficulties or problems in evaluating their students, ineffectiveness or uselessness of learning processes, deficient interest in learning English, the dominant use of local languages. However, our participants tried to deal with those challenges issues in teaching big or large classes. They tried to prepare several strategies that would help them to manage their classes including punishment, variety of games, quiz, pair work or group work, supporting media, and speaking test. These strategies worked for their classes although challenges were still there for them. Our participants also revealed that their efforts to reduce the challenges should be continuous as they thought that teaching English as a foreign language is not easy and new students come every year, suggesting that new challenges will also emerge in teaching large classes.

\section{REFERENCES}

[1] Abrar, M., Mukminin, A., Habibi, A., Asyrafi, F., Makmur, M., \& Marzulina, L. (2018). If our English isn’t a language, what is it? Indonesian EFL Student Teachers' Challenges Speaking English. The Qualitative Report, 23(1), 129-145.

[2] Ara, A., \& Hossain, K. A. (2016). Meeting the challenges of teaching large classes in context of Bangladesh. Research Journal of English Language and Literature, 4(4), 294-301.

[3] British Council. (2015). Maximizing learning in large classes. Ethiopia: Master Printing Press.

[4] Brown, H. D. (2001). Teaching by principles: An interactive approach to language pedagogy ( $2^{\text {nd }}$ ed.). New York: Longman.

[5] Brown, H. D. (2009). Principles of language learning and teaching ( $5^{\text {th }}$ ed.). New York: Longman.

[6] Creswell, J. W. (2012). Educational research: Planning, conducting and evaluating quantitative and qualitative research (4 $^{\text {th }}$ ed.). University of Nebraska-Lincoln: Pearson Publications, Inc.

[7] Day, C., \& Sammons, P. (2014). Successful school leadership. United Kingdom: Education Development Trust.

[8] Earthman, G. (2002). School facility conditions and student academic achievement. Williams Watch Series: Investigating the Claims of Williams v. State of California, Los Angeles, CA: UCLA's Institute for Democracy, Education, and Access. http://www.escholarship.org/uc/item/5sw56439

[9] Epri, M. L. (2016). A case study on the impact of large classes on student learning. DWU Research Journal, 24(1), 95-109.

[10] Finch, G. (2003). How to study linguistics: A guide to understanding language (2 ${ }^{\text {nd }}$ ed.). New York: Palgrave MacMillan.

[11] Habibi, A., Mukminin, A., Najwan, J., Haswindy, S., Marzulina, L., Sirozi, M., Harto, K., \& Sofwan, M. (2018). Investigating EFL Classroom Management in Pesantren: A Case Study. The Qualitative Report, 23(9), 2105-2123.

[12] Haddad, C. (2015). Practical tips for teaching large classes: A teacher's guide. Paris: United Nations Educational, Scientific and Cultural Organization.

[13] Hadi, M. J., \& Arante, L. T. (2015). Barriers in teaching English in large classes: Voice of an Indonesian English language teacher. Journal of Education, 1(1), 1-7.

[14] Hamra, A., \& Syatriana, E. (2010). Developing a model of teaching reading comprehension for EFL students. TEFLIN Journal, 21(1), 27-40.

[15] Harmer, J. (2007). The practice of English language teaching $\left(4^{\text {th }}\right.$ ed.). New York: Longman.

[16] Harmer, J. (2010). The practice of English language teaching ( $5^{\text {th }}$ ed.). New York: Longman.

[17] Hamers, J. F., \& Blanc, M. H. A. (2003). Bilinguality and bilingualism. Cambridge, UK: Cambridge University Press.

[18] Hayes, D. (1997). Helping teachers to cope with large classes. ELT Journal, 51(2), 106-116.

[19] Herlina, H., \& Holandiyah, M. (2016). Teaching speaking skill by using guided conversation technique through pair taping to the seventh grade students of SMP PTI Palembang. Edukasi: Jurnal Pendidikan dan Pengajaran, 2(2), 107-120.

[20] Khan, P. \& Iqbal, M. (2012). Overcrowded classrooms: A serious problem for teachers. Peshawar: Sarhad University of Science and Information Technology.

[21] Lazear, E. P. (2003). Educational Production. The Quarterly Journal of Economics, 116(3), 777-803.

[22] Leavy, P. L., \& Biber, S. N. H. (2011). The practice of qualitative research ( $2^{\text {nd }}$ ed.). London: SAGE Publications. 
[23] Marzulina, L. (2018). Learning strategy towards students' descriptive writing achievement taught by using pick - list - evaluate - active - supply - end strategy. Edukasi: Jurnal Pendidikan dan Pengajaran, 5(1), 63-75.

[24] Mukminin, A., Sari, S. R., Haryanto, E., Habibi, A., Hidayat, M., Marzulina, L., Nurulanningsih, N., \& Ikhsan, I. (2019). “They can speak English, but they don't want to use it." Teaching Contents through English in a Bilingual School and Policy Recommendations. The Qualitative Report, 24(6), 1258-1274.

[25] Pickering, C. (2008). Challenges in the classroom and teacher stress. Health and Learning Magazine, 6, $22-27$.

[26] Plank, S. B., \& Candliffe, B. (2011). A descriptive look at classroom quality in second and third grade classrooms. Baltimore: Baltimore Education Research Institute.

[27] Rohin, R. (2013). Teaching English in large classes in Afghanistan. Journal of Education, 1(1), 1-8.

[28] Sequeira, A. H. (2012). Introduction to concepts of teaching and learning. Journal of National Institute of Technology Karnataka, 1(1), 1-6.

[29] Sulistyowati, T. (2012). Making large classes smaller: the challenge of teaching English to young learners in Indonesia. TEYLIN 2, 170-178

[30] Thaher, M. (2005). Communication apprehension among an-najah national university students. An-Najah Univ. J. Res. 19(2), 627-678.

[31] Todd, R. W. (2012). The effects of class size on English learning at a Thai university. ELT Research Journal, 1(1), 80-88.

[32] Trang, N. M. (2015). Large classes: Universal teaching and management strategies. An International Peer-reviewed Open Access Journal, 2(1), 76-83.

[33] UNESCO. (2006). Practical Tips for Teaching Large Class. France: United Nations Educational, Scientific and Cultural Organization.

[34] Ur, P. (1996). A course in language teaching: Practice and theory. Cambridge: Cambridge University Press.

[35] Wang, Q., \& Zhang, N. (2011). Teaching large classes in China - English as a foreign language. China: Beijing Normal University.

[36] Wilson, V. (2002). Does small really make a difference? A review of the literature on the effects of class size on teaching practice and pupils' behaviour and attainment. Scottish Council for Research in Education (SCRE) Centre: University of Glasgow.

[37] Wilson, V. (2006). Does small really make a difference? An update. A review of the literature on the effects of class size on teaching practice and pupils' behaviour and attainment. Scottish Council for Research in Education (SCRE) Centre: University of Glasgow, 198-210.

[38] Younghusband, L. J. (2005). High school teachers' perceptions of their working environment in Newfoundland: a grounded theory study (10005) [Doctoral (PhD) thesis, Memorial University of Newfoundland]. http://research.library.mun.ca/id/eprint/10005

[39] Zhang, M. (2008). Challenges and solutions of teaching large classes. Education Science and Culture Magazine, 29, 68-69.

Dian Erlina is an associate professor, Universitas Islam Negeri Raden Fatah Palembang, Indonesia. Her research focuses on language teaching, TEFL, and English education and applied linguistics.

Lenny Marzulina is an associate professor, Universitas Islam Negeri Raden Fatah Palembang, Indonesia. Her research focuses on language teaching, TEFL, and English education and applied linguistics.

Kasinyo Harto is a full professor, Universitas Islam Negeri Raden Fatah, Palembang, Indonesia. His research interests are teaching and learning in higher education, multicultural education, educational management, and education in Muslim countries .

Muhamad Holandyah is an assistant professor, Universitas Islam Negeri Raden Fatah Palembang, Indonesia. His research focuses on language teaching, TEFL, and English education and applied linguistics.

Bunga Ayu Wulandari is an assistant professor, Universitas Jambi, Faculty of Teacher Training and Education, Indonesia. Her research focuses on language teaching, TEFL, and English education and applied linguistics.

Muhammad Fauzan is a lecturer, Universitas Jambi, Faculty of Teacher Training and Education, Indonesia. Her research focuses on language teaching, TEFL, and English education and applied linguistics.

Fridiyanto is an assistant professor, UIN Sulthan Thaha Saifuddin Jambi, Indonesia. His research interests include education, language education, multicultural education, educational policy and management.

Amirul Mukminin is a full professor, Universitas Jambi, Faculty of Teacher Training and Education, Indonesia. His research interests include education, language education, international education, educational policy and language policy. 